\title{
Evaluation of fruit tree waterstress condition and transpiration with heat flux sensors
}

\author{
Nagy, A. ${ }^{1}$, Riczu, P. ${ }^{1}$, Tamás, J. ${ }^{1}$, Szabó, Z. ${ }^{2}$, Soltész, M. ${ }^{2}$ \& Nyéki, J. ${ }^{2}$ \\ ${ }^{1}$ University of Debrecen, Centre of Agricultural Sciences and Engineering, Faculty of Agricultural and Food \\ Sciences and Environmental Management, Institute of Water and Environmental Management, \\ H-4032 Debrecen, Böszörményi 138, Hungary, attilanagy@agr.unideb.hu \\ ${ }^{2}$ University of Debrecen, Centre for Agricultural and Applied Economic Sciences, Faculty of Agricultural and \\ Food Sciences and Environmental Management, Institute for Horticulture, \\ H-4032 Debrecen, Böszörményi str. 138, Hungary
}

\begin{abstract}
Summary: In this study the transpiration properties and response to heat stress of Granny Smith and Jonagold apple species were measured. The examinations were set at an orchard near to Debrecen. The chosen trees were two years old, without fruits, in 201 container, placed in the mixture of mulch matrix, wood chips and sawdust and grown at the same climatic conditions. One of the most important goals was to determine the leaf area of the trees which is a basic data for transpiration modeling. Leaf area was larger (significance level $\mathrm{p}<0.05$ ) in the upper part of the canopy to achieve larger photosynthetic surface. Jonagold species with less leaf number ( $-18 \%$ compared to Granny Smith) reached almost the same canopy area, than Granny Smith, due to larger leaf area of Jonagold. Another aim was to measure the transpiration rate of the apple trees. The transpiration measurements were carried out by sap flow meter. Only a small transpiration difference can be found between species. During the investigation time there were wet and cool as well as dry and extremely hot periods. In the case of dry and extreme hot periods the transpiration is decreased, which causes decrease in transpiration and enhanced the water stress of trees.
\end{abstract}

Key words: leaf area index, evapotranspiration, water stress

\section{Introduction}

In Hungary about 100000 hectares of orchards can be found, from which apple is cultivated on one of the largest areas. The total area of apple and pear orchards is more than 45000 ha. Apple orchards cover about $60 \%$ of the total pomiculture in Hungary, although in the last period the production was reduced (Gonda and Apáti, 2011). The production of marketable horticulture products is difficult without quality horticulture practice, which in many cases is the primary condition of appropriate management and irrigation systems. The data of the Central Statistics Office show that $28 \%$ of the apple and pear orchards can be irrigated, but only $21 \%$ is irrigated. Since horticulture is a water demanding sector, high quality fruit-production is difficult without proper irrigation. Furthermore in some horticultural farms there is no irrigation applied, or its techniques is improper. There are several experiments going on around the world to develop methods of irrigation, which draw different technology combination for the water and energy saving micro-irrigation. One of the biggest professional challenges of the following years is to develop the water resource management for apple and pear trees. For this the water norm of the trees has to be identified in the different phenological stages, the irrigation turns, and technology and the transpiration surface.
In orchard plant's leaf area must determine not only in absolute terms, but compared with the growing area (T) also. The rate of two values called leaf area index (LAI), which is leaf area $\left(\mathrm{m}^{2}\right)$ per $1 \mathrm{~m}^{2}$ soil surface. The LAI is the most suitable index in the cultivation practice for the plant mass (Szász, 1988).

$$
L A I=\frac{L A}{T}\left(\mathrm{~m}^{2} / \mathrm{m}^{2}\right)
$$

LAI - as biophysical status - is in a close relationship with the amount of biomass, with the photosynthesis and transpiration scale (Nemani and Running, 1989). The size and number of leaf determine the leaf area (LA). The number of leaf produced is reduced by water stress, nutrient deficiencies and is under hormonal control. The leaf area index change species, stage of development, methods of cultivation, density of crop. Wagenmakers (1989) found that leaf area per tree of apples and pears decreased linearly with planting density. Verheij (1972) showed that with apple the leaf area per tree declined with increasing planting density even with unpruned trees, and was accompanied by a relative suppression of lateral growth in the lower parts of the trees.

The leaf area determines the area of transpiration. Transpiration is taking place through the stomas of the lower epidermis (Boyer, 1985). The stoma is a pore, found in the leaf and stem epidermis that is used for gas exchange. The 
pore is bordered by a pair of specialized parenchyma cells known as guard cells which are responsible for regulating the size of the opening and are the closest thing a plant has to a muscle. (Boldizsár, 2007). In the case of different apple varieties, the number of stomas can be different: 200-450 pores $/ \mathrm{m}^{2}$ (Cowart, 1935; Slack, 1974). The apple varieties growing faster the density of stomas is higher, while smaller varieties have less stoma density (Beakbane and Majumdar, 1975). Cowart (1935) established that less stoma can be found in the leaves of lower position. The extent of transpiration depends on several physical factors as well as the opening or the closing of the stomas (Jackson, 2003). One of the most significant factors influencing transpiration is the wind (Mansfield and McAnish, 1995). Beukes (1984) established a negative correlation between transpiration and wind velocity. The transpiration rate is also determined by the leaf temperature and the available moisture content of the soil. Transpiration is increasing if more water is available in the soil: in case of optimal water supply apple trees transpirated more water and the conductance of the stomas increased (Alleyne et al., 1989; Gower et al., 1990; Frenandez et al., 1997). During the day the water potential of apple and pear trees is decreasing with the increasing transpiration: Goode and Higgs (1973) observed the lowest water potential in noontime. Landsberg et al. (1975) and Fernandez et al. (1997) examined apple and pear trees under droughty and control conditions. They concluded that the closing of the stomas is an effective physiological control that reduces the rate of transpiration.

\section{Materials and methods}

In this study the transpiration properties and response to heat stress of Granny Smith and Jonagold apple species were measured. The examinations were set at an orchard near to Debrecen without irrigation. The investigation period was from $5^{\text {th }}$ of July to $5^{\text {th }}$ of September 2011 , with 5 day pause, caused by technical problems. The chosen trees were two years old, without fruits, in 201 container, placed in the mixture of mulch matrix, wood chips and sawdust and grown at the same climatic conditions. Since different rootstocks affect differently the watermanagement of apple trees, species with the same rootstock (MM106) were chosen. One of the most important goals was to determine the leaf area of the trees which is a basic data for transpiration modeling. Another aim was to measure the transpiration rate of the apple trees. The transpiration measurements were carried out by sap flow meter. After determining the transpiration and transpiration surface of the examined trees, it is possible to define the transpiration rate for one square meter.

\section{Leaf area determination}

On $30^{\text {th }}$ September 2011 the leaves were collected from each tree. During the leaf sampling the canopy was divided into two parts. The leaves from the lower branches were separately collected from the leaves of the upper branches. Scanning of the leaves was carried out in the laboratory of the Institute of Water- and Environmental Management of the Centre for Agricultural and Applied Economic Sciences of the University of Debrecen. The leaf areas were measured by Area Meter 100 (AM 100) leaf area scanner developed by the Analytical Development Company. After scanning, the data were stored in the memory of the AM 100, then they were downloaded to a computer. Nevertheless the digital display of the device ensures a permanent monitoring of the measurement data. By means of the scanner, not only the surface area of the leaves with different sizes and colours, but also of the leaves damaged by pests could be determined. After each scanning the length and width of the leaf, the average and total area and the number, the time and the date of the scanning were displayed and stored.

\section{Transpiration measurement}

The transpiration was measured by Sap flow meter based on Stem Heat Balance theory. Sensors was set on the trunk of the apple trees. The Dynagage sap flow sensor consists of a flexible heater, a thermopile to measure radial heat loss, and differential thermocouple pairs to measure the axial temperature differences $q_{u}-q_{d}$. All of these sensors and heater are mounted on a cork substrate and housed inside white, reflective foam, thermal insulating collar. Once the sensor is installed on the stem surface, both the sensor and the stem sections above and below the sensor are completely covered by a heat insulator to minimize thermal perturbations caused by the ambient environment. Power is supplied continuously to the heater from a regulated DC power source. The Dynamax loggers have a power down mode so that power is saved at night and the stem is preserved from overheating. During the power down mode and at the transitions to power on, the sap flow is not computed to maintain the accumulated flow accurately during this unbalanced transition. Figure 1 shows a stem section and the possible components of heat flux, assuming no heat storage.

The heater surrounds the stem under test and is powered by a DC supply with a fixed amount of heat, Qh. Qh is the

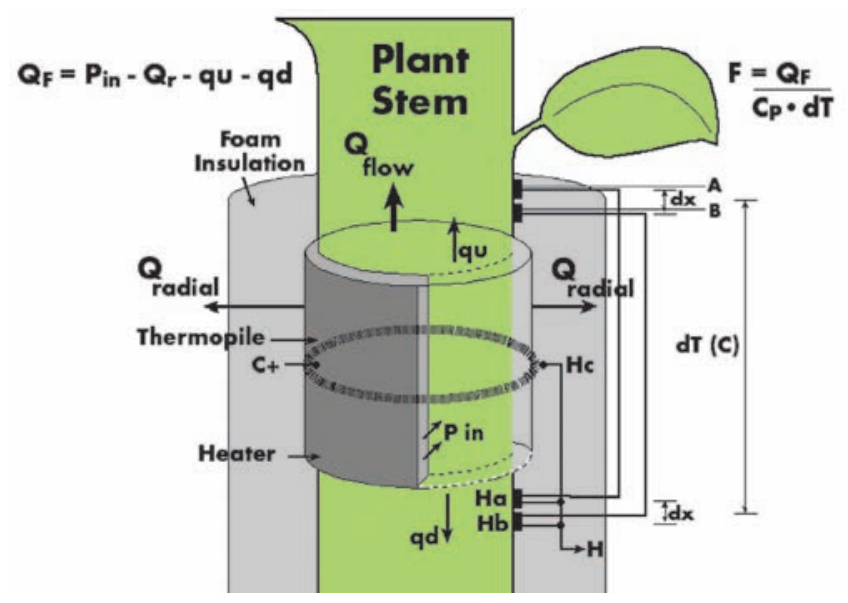

Figure 1. Stem gage schematics (Dynamax manual) 
equivalent to the power input to the stem from the heater, Pin. Qr is the radial heat conducted through the gage to the ambient. Qv, the vertical, or axial heat conduction through the stem has two components, $\mathrm{Qu}$ and $\mathrm{Qd}$. By measuring Pin, $\mathrm{Qu}, \mathrm{Qd}$, and Qr, the remainder, Qf can be calculated. Qf is the heat convection carried by the sap. After dividing by the specific heat of water and the sap temperature increase, the heat flux is converted directly to mass flow rate. Flow rate is expressed as g moisture/hour.

\section{Results and discussion}

\section{Transpiration surface}

The apple tree leaves collected at the end of the final phenological state were scanned and the total transpiration and the average leaf areas were determined (Table 1.). Concerning Granny Smith species 144 leaves from lower part of canopy and 244 from upper part were collected. In the case of Jonagold 136 leaves from lower part of canopy and 183 from upper part were collected. Comparing the leaf size within and transpiration surfaces, it can be stated, that in the case of both species the photosyntetically active canopy area was larger in the upper part of the canopy. This was simply caused by the structure of tree for better utilization of the light. Leaf area was also larger (significance level $\mathrm{p}<0.05$ ) in the upper part of the canopy to achieve larger photosynthetic surface. Naturally the transpiration is also higher in this region.

Table 4. Canopy and leaf area of Jonagold and Granny Smith apple species

\begin{tabular}{|c|c|c|}
\hline & \multicolumn{2}{|c|}{ Leaf area $\left(\mathrm{cm}^{2}\right)$} \\
\hline & Granny Smith & Jonagold \\
\hline$\sum$ & \multicolumn{2}{|c|}{ Upper part of canopy } \\
\hline & 5413.5 & 4723.7 \\
\hline 1 leaf (mean) & 22.19 & 25.81 \\
\hline$\sum$ & \multicolumn{2}{|c|}{ Lower part of canopy } \\
\hline 1 leaf (mean) & 2187.9 & 2542.3 \\
\hline & 15.19 & 18.69 \\
\hline$\sum$ & \multicolumn{2}{|c|}{ Whole canopy } \\
\hline 1 leaf (mean) & 7601.4 & 7265.9 \\
\hline
\end{tabular}

Comparing the measured area parameters between species, there were some differences is found. Though only a slight total canopy differences was found $(4.44 \%$ differences between species) the average leaf area was significantly (significance level $\mathrm{p}<0.05$ ) larger in the case of Jonagold species. That means Jonagold species with less leaf number reached almost the same canopy area, than Granny Smith, since there is $18 \%$ differences between the species concerning number of the leaves, which probably due to species properties.

\section{Transpiration of apple trees}

For the characterization of the water use and stress of the fruit trees, the transpiration of them was investigated, concerning the climatic parameters, such as temperature and rainfall. In order to compare the transpiration properties of apple trees, the measured sap flow (g/day) was adjusted to one square meter of canopy. On the base of values of transpiration only a small difference can be found between species. Concerning the whole transpiration period, there was an only $4874 \mathrm{~g}$ difference in transpiration, which is less than 51 . Therefore it can be declared, that significant difference in transpiration can not be found between the examined species.

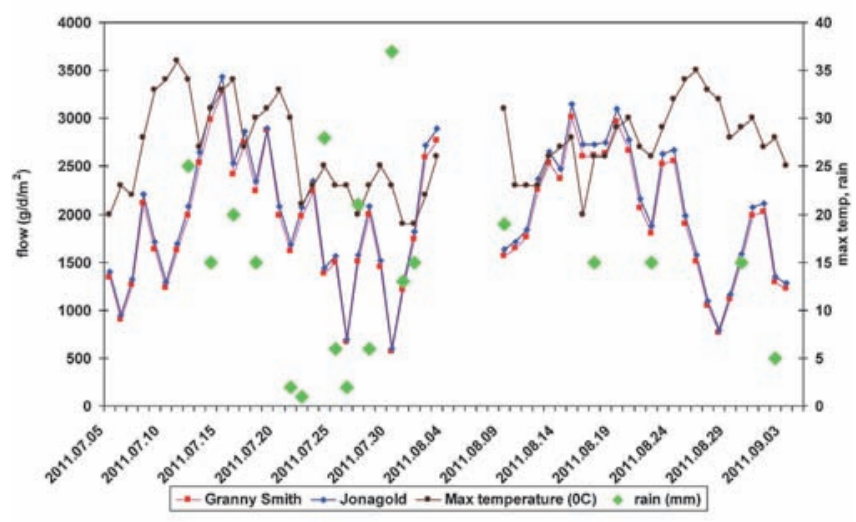

Figure 2. Transpiration of $1 \mathrm{~m} 2$ canopy and the climatic conditions

During the investigation time there were wet and cool as well as dry and extremely hot periods. In the case of dry and extreme hot periods $\left(9^{\text {th }}-13^{\text {th }}\right.$ of July and $24^{\text {th }}-29^{\text {th }}$ August $)$ the transpiration is decreased, due to the lack of water in the soil and the huge water potential. The decreased transpiration means that stomatal closure occurred thus, according to several studies (Pethö, 1996) the photosynthesis is also blocked and reach its minimum. Not only the transpiration is blocked but also the $\mathrm{CO}_{2}$ uptake, therefore reactive hidroxil radicals are produced which are harmful for the chloroplasts and cell membranes, which eventually causes the water stress symptoms in plants.

Concerning the wet periods there was sufficient water supply for the apple trees. While the temperature increased the transpiration increased as well, furthermore, positive correlation ( $\mathrm{r}=0.77)$ was found between the maximum temperature and transpiration.

\section{Conclusions}

In the case of both species the photosyntetically active canopy area and leaf area was larger in the upper part of the canopy for better utilization of the light. Leaves of Jonagold tree are significantly larger than Granny Smith which probably due to species properties. In the case of dry and extreme hot periods the transpiration is decreased, water stress occurred. Since there is a positive correlation was found between the 
maximum temperature and transpiration properties Sap Flow meter can be suitable for not only transpiration monitoring, but also for irrigation scheduling and water stress assessment.

\section{Acknowledgements}

This study is funded by TECH_08-A3/2-2008-0373 and TECH_08-A4/2-2008-0138 projects.

\section{References}

Allayne, V., Larsen, F. E. \& Higgins, S. S. (1989): Water relations of container-grown, virus tested and common apple (Malus domestica Borkh) rootstocks. Scientia Horticulturae. 38: 117-129.

Gonda, I. \& Apáti, F. (2011): Almatermesztésünk helyzete és jövőbeni kilátásai. [The currently status and future prospects of our apple production.] In: Tamás, J. (eds.): Almaültetvények vízkészletgazdálkodása. [Water resource management of apple orchards.] Debreceni Egyetem, AGTC, Kutatási és Fejlesztési Intézet, Kecskeméti Főiskola, Kertészeti Főiskolai Kar, Debrecen. 13-25.

Beakbane, B. \& Majumdar, P. K. (1975): A relationship between stomatal density and growth potential in apple rootstocks, J. Hortic. Sci. 50: 285-289.

Beukes, D. J. (1984): Transpiration of apple trees as related to different meteorological, plant and soil factors. J. Hortic. Sci. 59: 151-159.

Boldizsár, A. (2007): Evaporation and microclimate studies in the Balaton lake reeds. PhD thesis. Keszthely. 27. p.

Boyer, J. S. (1985): Water transport. Annual Review of Plant Physiology. 36: 473-516.

Cowart F. F. (1935): Apple leaf structure as related to position of leaf upon the shoot and to type of growth. Proc. Am. Soc. Hortic Sci. 33: 145-148.

Fernandez, R. T., Perry, R. L. \& Flore, J. A. (1997): Drought response of young apple tree rootstocks. II. Gas exchange, chloro- phyll fluorescence, water relations, and leaf abscisic acid. J. Amer. Soc. Hort. Sci. 122: 841-848.

Goode, H. G. \& Higgs, K. H. (1973): Water potential-water content relationships in apple leaves. J. Exp. Bot. 30: 965.

Gower, S.T., Kucharik, C. J. \& Normann, J. M. (1999): Direct and indirect estimation of leaf area index, fapar, and net primary production of terrestrial ecosystms. Remote Sensing of Environmental. 70: 29-51.

Jackson, J. E. (2003): Biology of apples and pears. Cambridge: Cambridge University.

Landsberg, J. J., Beadle, C. L., Biscoe, P. D., Butler, D. R., Davidson, B., Incoll, L. D., James, G. B., Jarvis, P. G., Martin, P. J., Neilson, R. E., Powell, D. B. B., Slack, E. M., Thorpe, M.R., Turner, N. C., Warrit, B. \& Watts W. R. (1975): Diurnal energy, water and $\mathrm{CO}_{2}$ exchanges in an apple (Malus pumila) orchard. $J$. Applied Ecol. 12: 659-684.

Mansfiled, T. A., McAinh, M. R. (1995): Hormones as regulators of water balance. [In: Plant Hormones. (Ed.): Davies P. J. Dordrecht]: Kluwer Academic Press. 598-616.

Nemani, R. R. \& Running, S. W. (1989): Testing a theoretical climate-soil-leaf area hydrologic equilibrium of forests using satellite data and ecosystem simulation. Agricultural and Forest Meteorology Volume 44, (3-4): 245-260.

Pethő, M. (1996): Mezőgazdasági növények élettana, Akadémia Kiadó, Budapest

Slack, E. M. (1974): Studies of stomatal distribution on the leaves of four apple varieties. Journal of Horticultural Science 49: 95-103.

Szász, G. (1988): Agro meteorology, Mezőgazdasági Kiadó, Budapest, 462.

Verheij, E. W. M. (1972): Competition in apple, as influenced by Alar sprays, fruiting, pruning and tree spacing. $\mathrm{PhD}$ thesis. Wageningen.

Wagenmakers, P. S. (1989): High-density planting system trial with pear. 4. International Symposium on Research and Development on Orchard and Plantation Systems, Dronten (Netherlands), 29 Aug-2 Sep 1988. 